\title{
"When the Chips Are Down": A Response to Ambasciano
}

\author{
DAVID G. ROBERTSON*
}

An Unnatural History of Religions (hereafter, AUHR) begins with a question: "How come that, despite centuries of scientific research, the main academic discipline dedicated to the historical study of religion has been - and still is - so blindly devoted to an apologetic study of its research subject?"1 Ambasciano's answer is multifaceted, but centres on the cognitive processes which mean that scientific reasoning is more taxing and less "natural" than emotional, intuitive, motivated reasoning. This I do not dispute, though I approach the subject as a critical historian, rather than a cognitivist. But in this short response, I want to further develop an answer which Ambasciano touches on in a few places in AUHR which focus on the relationship between the discipline and the various institutions and professional organisations in which we operate as scholars. The answer, I suggest, is that Religious Studies (hereafter, RS) ${ }^{2}$ remains confessional and fideistic because most of the scholars who constitute it want it to be that way - much as in the heyday of its predecessor, the History of Religions (hereafter, HoR).

That no other discipline has been such a haven for pseudoscience within the modern academy is a point that Ambasciano makes repeatedly and forcefully throughout $A U H R$, as well as the introduction to this issue.

* For reasons that will become obvious, I wish to make it clear that this response is my own opinion, and does not represent the position of the majority of my colleagues at the Open University, the British Association for the Study of Religion, nor the Religious Studies Project.

1 Leonardo Ambasciano, An Unnatural History of Religions: Academia, Post-truth and the Quest for Scientific Knowledge, London - New York: Bloomsbury 2019, xi.

2 In the UK and North America, RS continues to be the standard disciplinary terminology, though in Australia, Studies in Religion (avoiding the term "Religious") is preferred, and an increasing minority of scholars are adopting this elsewhere in the Anglophone world. In mainland Europe, Science of Religion is dominant (in different language variants). I will stick with RS here for readability. In each case, however, the break with the problematic legacy of HoR is not as clean as the change of terminology might lead us to believe. 
As a critical historian, the pseudoscience that most concerns me is the continued presence of metaphysical claims, in the form of sui generis essentialism. This has become abundantly clear to me in my current research project, a genealogy of the category Gnosticism in contemporary RS. Beginning in the late nineteenth century, Gnosticism underwent a twostage process of essentialization, where a polemical term was transformed first into a historical tradition, and then again in post-war HoR into an ahistorical sui generis essence - a perennial tradition of transformative, elite knowledge. I did not intend the project to become a critique of the HoR, but it quickly became plain that this ahistorical Gnosticism (or, frequently, "Gnosis", to distinguish the supposed essence from its historical manifestations) was the product of scholars who were pivotal to the foundation of the HoR. We could even describe Gnosticism, at least as it came to be understood, as HoR's crystallization: ahistorical, sui generis, fideistic, perrennialist, elitist, deinstitutionalised Protestantism presented as a necessary corrective, and even salvation. ${ }^{3}$

The connection to the HoR is not only a thematic comparison, however, but a direct historical relationship. The same people who set the narrative on Gnosticism as we know it today also established the International Association for the History of Religions (hereafter, IAHR) and became central figures of the burgeoning HoR and its later flowering as RS in the United States and United Kingdom. Moreover, of the founding committee of the IAHR in 1950, four - inaugural President Gerardus van der Leeuw, his successor Raffaele Pettazzoni, Vice-President HenriCharles Puech, and Numen co-editor Mircea Eliade - were also in attendance at that year's Eranos conference, a private meeting named by Rudolf Otto, initiated by Alice Bailey and centred around Carl Jung. ${ }^{4}$ Already, Puech had recently announced the discovery of the Nag Hammadi corpus, a collection of texts which promised to confirm the theories of Jung, Hans Jonas and Giles Quispel (another Eranos delegate) regarding the nature of Gnosticism. Had they actually read these texts, it would not have confirmed but in fact significantly undermined them; but they had not. ${ }^{5}$ Nevertheless, Puech and Quispel organised the purchase of one of the codices for the Jung Institute, and were a driving force

3 On this, see Karen L. King, What is Gnosticism?, Cambridge, MA: Harvard University Press 2003.

4 See Steven M. Wasserstrom, Religion after Religion: Gershom Scholem, Mircea Eliade, and Henry Corbin at Eranos, Princeton: Princeton University Press 2001.

5 Michael A. Williams, Rethinking "Gnosticism": An Argument for Dismantling a Dubious Category, Princeton, NJ: Princeton University Press 1996; K. L. King, What is Gnosticism?... 
behind the frustratingly long and difficult attempts to translate and publish the Nag Hammadi material.

Many of these same people were then involved in the Messina Congress of the IAHR in 1966, which attempted to establish working definitions for Gnosticism and Gnosis. These definitions incorporated Jung's ideas, and were co-written by Hans Jonas, the estranged pupil of Heidegger and Rudolph Bultmann. While these definitions were not ultimately widely adopted, they did canonise the distinction found even today between Gnosticism (defined as a historical phenomenon of Late Antiquity) and Gnosis (defined as an ahistorical phenomenon, whether existential or psychological in nature). This is a clear example of the HoR legitimising ideas without any scientific grounding. The phenomenology of religion makes the difference between positing a classificatory type and a phenomenological essence permeable, to say the least. How are we to ascertain the existence of this special knowledge, Gnosis? Presumably, through the privileged insight of homo religiosus - but not through scientific investigation.

Once this is clarified, it becomes understandable that Gnosticism should continue to act as a dog-whistle for HoR ideas in contemporary scholarship. Though not essentialist in and of itself, the Western Esotericism school, centred on Wouter Hanegraaff at the University of Amsterdam, is typified by the use of the term Gnosis, which is presented as a third "epistemological pillar" in Western history, distinct from both Faith and Reason. ${ }^{6}$ This is a model drawn from Gilles Quispel, and a definition of Western Esotericism originating, via Antoine Faivre, with another Eranos delegate, the Islamicist Henry Corbin. Although Hanegraaff has moved towards using these categories discursively rather than substantively, to outline historical processes in the legitimisation and rejection of knowledge, the tripartite model remains part of this same lineage of Eranos scholars. Moreover, for some students and scholars, Gnosis continues to function as an epistemological and ontological legitimiser of Esotericism (and perhaps, Western Esotericism as an academic field of study acts as an epistemological and ontological legitimiser of esotericism as practice). ${ }^{7}$

6 Wouter J. Hanegraaff, New Age Religion and Western Culture: Esotericism in the Mirror of Secular Thought, Brill: Leiden 1996; cf. id., "On the Construction of 'Esoteric Traditions"', in: Antoine Faivre - Wouter Hanegraaff (eds), Western Esotericism and the Science of Religions, Leuven: Peeters 1998, 11-62.

7 For an example of how minority "area studies" scholarship can act as a forum for apologetics, see Markus Altena Davidsen, "What is Wrong with Pagan Studies? A Review Essay on the Handbook of Contemporary Paganism", Method and Theory in the Study of Religion 24/2, 2012, 183-199: 183. 
Another example is the Gnosticism, Esotericism, Mysticism (GEM) program, based at Rice University, Texas, and founded by April DeConick and Jeffrey Kripal. DeConick is predominantly a Biblical scholar, and Gilles Quispel was her doctoral examiner. However, her most recent work has been more comparative, presenting Gnosticism as a "counter-cultural" religious type with many manifestations, most recently the New Age movement. ${ }^{8}$ The work is explicitly essentialist and implicitly confessional, but as I have critiqued it in some detail elsewhere, I won't belabour the point here. ${ }^{9}$

Kripal's use of Gnosticism is particularly pertinent for this essay. Gnosticism, in his work, represents a "new comparitivist" methodology for RS, intended to transcend both Faith and Reason. ${ }^{10}$ Despite his protests to the contrary, ${ }^{11}$ in arguing for the ontological reality of paranormal events and the transformative potential of religious scholarship, Kripal repeats the Eliadian notion of the historian of religions as "homo religiosus", and Gnosticism is again presented as elite knowledge. From The Serpent's Gift (2006) onwards, this develops into a critique of the academy, and indeed science itself. In this book, "Gnostic" takes on a more complex role in a broader and more complex argument, which seems to be spiritual, institutional and epistemological at the same time:

I take the ancient gnostic myth as a powerful and ultimately positive parable for all of us who would wish to "grow up", leave the garden of our sexual and religious innocences (and the two, I will argue, are almost always connected), and venture forth into larger, if admittedly more ambiguous, visions of the world, ourselves and the divine. ${ }^{12}$

There are some obvious points of comparison with Jung: an autobiographical impulse with a heavy mythological style; an anomalous "experience" which goes on to inspire new lines of thinking; the aim of integrating the rational and irrational aspects of the human mind in a new paradigm. And like Jung, he uses Gnosticism to indicate this new para-

8 April D. DeConick, The Gnostic New Age: How a Countercultural Spirituality Revolutionized Religion from Antiquity to Today, New York: Columbia University Press 2016; ead., "The Countercultural Gnostic: Turning the World Upside Down and Inside Out", Gnosis: Journal of Gnostic Studies 1, 2016, 7-35.

9 David G. Robertson, "A Gnostic History of Religions", Method and Theory in the Study of Religion 32/1, 2020, 75-88.

10 Jeffrey J. Kripal, Secret Body: Erotic and Esoteric Currents in the History of Religions, Chicago: The University of Chicago Press 2017, 122-123.

11 Jeffrey J. Kripal, “Gnosisssss - A Response to Wouter Hanegraaff”, Religion 38/3, 2008, 277-279.

12 Jeffrey J. Kripal, The Serpent's Gift: Gnostic Reflections on the Study of Religion, Chicago: The University of Chicago Press 2006, 1. 
digm of knowledge, although he admits to "employing the trope of Gnosticism in rhetorical and essentially theological ways to advance my own intellectual agendas". ${ }^{13}$ But in terms of his theoretical approach to the study of religion, the clearest point of comparison is with Eliade, though I am not the first person to make the comparison. ${ }^{14}$

Ambasciano notes that the HoR fed the New Age movement through the mass publication of Eliade's books (in some cases, by the Jungian Bollingen Press), ${ }^{15}$ and as Wasserstrom pithily put it, "it is the New Age to which much of the spirit of History of Religions has fled". ${ }^{16}$ It is striking, then, that DeConick and Hanegraaff both make a connection between Gnosticism and the New Age. Although the comparisons are substantively different, they share the idea that the Gnosticism of Late Antiquity is just one flowering of a perennial attitude called Gnosis, which re-emerged in Catharism, Esotericism, Existentialism and/or the New Age movement. What their analyses miss, however, is that Gnosticism parallels New Age because it was invented by the same people, at the same time. The heresiological legend of the Gnostics becomes part of the cultic milieu through the Theosophical society, takes on a psychological aspect through Jung, and sacralises a narrative of individualism which reproduces the unregulated free market social order of the post-War West - precisely the same genealogy as the New Age movement. For example, DeConick acknowledges that Blavatsky and Jung are "the grandmother and grandfather of New Age religion", but not that Jung's knowledge of Gnosticism came largely from G. R. S. Mead, who was a student of Blavatsky. ${ }^{17}$ The protoNew Age Theosophical teachings influenced later academic understandings of Gnosticism, not the other way around. The critique of institutions, and the emphasis on experience and individual growth, were read into these texts at the same time and in the same social context as the New Age movement was forming with these ideas at its core.

Tellingly, both DeConick and Kripal are disparaging of the critical study of religion. DeConick laments "trendy" or "postmodern" academic work which has meant that "since the 1980s definitions in academia have

13 Ibid., 11.

14 T. David Brent (Eliade's literary executor), cited in J. J. Kripal, Secret Body..., 402409; Ken Chitwood, "Human Consciousness and Religious Reality" [online], Religious Studies Project, <https://www.religiousstudiesproject.com/2015/09/24/human-consciousness-religious-reality/>, 24 September 2015 [2 March 2020]; Hugh Urban, "Authors of the Impossible: The Paranormal and the Sacred: By Jeffrey J. Kripal", History of Religions 52/2, 2012, 192-195.

15 L. Ambasciano, An Unnatural History..., 116-117.

16 S. M. Wasserstrom, Religion after Religion..., 238.

17 A. D. DeConick, Gnostic New Age..., 349. 
become impossible to maintain". ${ }^{18}$ I am probably one of those scholars with a "chip on their shoulder" who Kripal describes as "out to prove religion wrong, to reduce it to psychological, social or economic forces". 19 Like DeConick, Kripal sees the non-confessional academic study of religion as a problem to be overcome, though he remains "committed both to the most robust rational-critical methods and to the metaphysical reality that is the object (really, I suspect, the subject) of religious experience and expression". ${ }^{20} \mathrm{He}$ states with approval that "historians of religions ... are often closet mystics" 21 - a claim I would agree with, although I reach quite different conclusions about the ramifications of this for contemporary Religious Studies. I am committed to keeping a strict separation between the etic and emic, whereas Kripal is committed to not doing so. ${ }^{22}$

Thus far, I am in complete agreement with Ambasciano. Where we disagree is that, rather than the cognitive study of religion, I advocate for a critical-historical approach where the idea of religion becomes the subject, especially when it is studied as part of the broader colonial episteme in which terms like "religion", "the secular", "politics", "race" and so on make sense. Cognitive studies can tend towards reifying certain discourses by disregarding their socio-historical contingency, and so I suspect that by themselves, cognitive studies will not allow us to escape that episteme. However, AUHR shows that critical and cognitive approaches can work together in order to establish a post-colonial approach to the study of "religion".

This essay started with the question which opens $A U H R$; now, I want to turn to the question which closes it: "Science \& democracy or post-truth \& pseudoscience: whose side are you on?"23 While I am certain which side I am on, we have to take into account that the vast majority of scholars are on the other side, and do not accept or even want to hear such critiques. What does this mean for the field? Can we reconceptualise it - and, perhaps more pertinently, should we? Ambasciano writes: "For the sake of the survival of the social-scientific study of religions, the discipline called HoR must go." ${ }^{24}$ I wonder if we should take this further, and extend it to $\mathrm{RS}$ more broadly. I am beginning to suspect that RS as constituted today is not the route to a scientific study of religion, but rather a ring-pass-not,

18 Ibid., 5-6.

19 J. J. Kripal, Secret Body..., 104.

20 Ibid., 128-129.

21 Jeffrey J. Kripal, Roads of Excess, Palaces of Wisdom: Eroticism and Reflexivity in the Study of Mysticism, Chicago: The University of Chicago Press 2001, 109.

22 J. J. Kripal, Secret Body..., 126.

23 L. Ambasciano, An Unnatural History..., 178.

24 Ibid., xvii. 
serving to continue the legitimisation of phenomenological essentialism and fideism in the academy, as Fitzgerald has forcefully argued. ${ }^{25}$ Perhaps, then, it is time to move past it.

When I have raised this unpopular position in the past, my colleagues have defended RS by arguing that religion, as a powerful and problematic discourse in the West, and beyond, surely deserves study. Indeed, I myself got into RS because I wanted to understand this mysterious force, religion, which seemed to exert such a powerful influence on history and on individuals. But I found a chimera, an illusion, and the discipline of RS there to uphold it, legitimise it, and shield it from critique. Yet the end of RS/ HoR as a discipline and department does not mean the end of the study of this powerful and problematic discourse, and those of us with jobs will simply become parts of broader departments - presuming, of course, that we have adequate methodological "chops" to do so. Indeed, it often seems that those most keen to defend RS are precisely those with the most to lose from such a development. As Ambasciano writes, "when the chips are down, classical HoR would do away with all those scholars that, in one way or another, threaten the emic, fideistic core of the discipline", ${ }^{26}$ consider, if you will, DeConick and Kripal's affronted dismissal of critique under the banner of Gnosticism. As Tomoko Masuzawa puts it, HoR scholars fear that critique, "if taken seriously, would have the effect of destroying the pith of 'religion' as we know it". ${ }^{27}$ Others have suggested that by allowing RS/HoR to decline, we end up ceding ground to the theologians and others with normative agendas. But I am not so sure.

Going back to the resistance to critique, I am frequently told that my work is just "arguing about definitions", and doesn't matter to "real people on the ground". Such a refusal to explicitly theorise, of course, means that one is accepting the implicit theorisation. This lack of theorisation is increasingly reinforced institutionally by "balkanisation", with RS departments becoming a collection of area studies scholars, each representing one of the so-called World Religions. As these scholars are less likely to be trained in theory and are more likely to be representatives of their particular tradition, the possibility of progress has declined in recent decades. This further encourages critical and scientific approaches to be given short shrift in most university courses and readers - and indeed, courses on method and theory, and the history of the discipline, are in decline.

25 Timothy Fitzgerald, The Ideology of Religious Studies, New York: Oxford University Press 2000.

26 L. Ambasciano, An Unnatural History..., 33.

27 Tomoko Masuzawa, The Invention of World Religions: Or, How European Universalism was Preserved in the Language of Pluralism, Chicago: University of Chicago Press 2005, 217. 
Courses focused on Gnosticism, Material Religion, Lived Religion, or any of the other nommes du guerre that HoR uses today, however, continue to thrive.

It is these scholars who will rise to power, due to their support (explicit or tacit) from religious interest groups, and who will go on to shape the narrative for media and policy makers. We see this most clearly in the recent British Academy report on "Theology and Religious Studies Provision in UK Higher Education", which through ignorance or deliberate dissemblance doesn't differentiate between RS and Theology, describing the whole field as "the study of the divine". ${ }^{28}$ Digging into the figures in the British Academy report, however, it is clear that the dire situation presented is more accurate in the case of Theology than RS, but in effect, the minority voice in the TRS brand is drowned out, and the RS simply ignored, with TRS reduced to "the study of the divine". The policy line from groups such as TRS-UK (a group which represents Theology and Religious Studies [TRS] departments and groups in the UK) is that the TRS "brand" benefits both Theology and Religious Studies departments by presenting a larger "united front", and that the study of religion would be impoverished without both perspectives. Yet the conversation is dominated by theologians, and the British Academy only recognises TRS, not the British Association for the Study of Religion nor any other group representing only Religious Studies scholars. By co-opting and then disenfranchising RS scholars and organisations, TRS ultimately benefits religionists more than those with scientific, social-scientific, or critical approaches.

All of which is to say that the problems of HoR and modern RS - which Ambasciano describes as the prominence of pseudoscience - are not problems to be solved, but something baked into the very logic of religion as a category, and RS as a discipline. This was a point made forcefully by Timothy Fitzgerald in The Ideology of Religious Studies, but in the twenty years since its publication, the possibility of establishing a new, critical study of the discourse on religion does not seem to have improved. Which side am I on? If I am forced to choose between abandoning RS/HoR as a specific field and department, or being represented by theologians and religionists with a commitment to fideism, essentialism and pseudosci-

28 The British Academy, "Theology and Religious Studies Provision in UK Higher Education" [online], <https://www.thebritishacademy.ac.uk/publications/theology-religious-studies-provision-uk-higher-education>, May 2019 [27 February 2020]. TRSUK's response is at <https://trs.ac.uk/news/trs-uk-official-response-to-british-academy-report-on-theology-and-religious-studies-provision-in-uk-higher-education/>, [27 February 2020]. 
ence, I will choose the former. For this alone offers the possibility of escaping the problematic legacy of the History of Religions. 


\section{SUMMARY}

\section{"When the Chips Are Down": A Response to Ambasciano}

The author comments on Leonardo Ambasciano's book An Unnatural History of Religions: Academia, Post-truth and the Quest for Scientific Knowledge (2019) and develops the line of its argument that a fideistic, sui generis, confessional History of Religions tradition continues due to the tacit support from scholars, institutions and organisations. Gnosticism is presented as a case study, showing how it exemplifies core critiques of HoR, and is supported by the same scholars and institutions, particularly the IAHR. The author then considers the recent British Academy report into Theology and Religious Studies in the UK to argue that the HoR tradition in contemporary Religious Studies is not a "problem to be solved", but rather something at the very basis of the discipline. The argument is therefore made that there cannot be a truly scientific academic study of religion while RS exists.

Keywords: History of Religions; Religious Studies; Theology and Religious Studies; British Academy; Gnosticism; critique; critical religion.

The Open University

Walton Hall

Milton Keynes

MK7 6AA

United Kingdom
DAVID G. ROBERTSON

david.robertson@open.ac.uk 